\title{
SOCIAL CONTROL AND INFLUENCE IN NINETEENTH CENTURY INDONESIA: OPIUM FARMS AND THE CHINESE OF JAVA*
}

\author{
James R. Rush
}

No theory in particular informed the evolution of Dutch administrative institutions in Java. Government emerged willy-nilly in response to immediate needs; one ad hoc arrangement followed another until precedents were established and past practice came to inform the nature of each successive elaboration. The process occurred over centuries. This slow evolution of institutions of authority in Dutch Java encouraged collaboration with indigenous elites and a gradual adjustment to their patterns of governance. Thus, a fundamental characteristic of the colonial state in Java as it had emerged by the mid-nineteenth century was Dutch dependence upon elite indigenous intermediaries for the day-to-day maintenance of social control and authority. As students of Java are well aware, the Dutch Colonial Service was an administrative head which was fitted upon the broad shoulders of the Javanese priyayi, who continued to govern their provinces and districts under Dutch command. In a similar fashion Java's leading Chinese watched over their people, maintaining cohesiveness and order, and in both formal and informal ways helping to maintain the calm orderliness (rust en orde) which the Dutch so valued.

Both of these groups, the priyayi and the Chinese, exercised authority in part through social preeminence, and in part through institutional structures which reinforced their social preeminence with official authority, and in the Chinese case, dramatic economic advantages. These elites did not relate to the Dutch as whole groups, but rather as individuals, families, and factions; and thus the Dutch were able to exercise control over them, that is, to prevent uniform opposition, by manipulating their access to official legitimacy and the means of exercising power-positions in pangreh pradja for the Javanese, and, for the Chinese, appointments as Chinese officers and revenue farmers. But the Dutch could not be too heavyhanded or capricious in these manipulations, for in practical terms their authority depended in considerable measure upon the collaboration of these groups. The system of governance that evolved, therefore, was characterized by an accommodation of Dutch, priyayi, and Chinese interests.

This paper examines briefly the means by which Java's leading Chinese, the wealthy peranakan, worked within this system. In collaboration with Dutch authority, but also with the priyayi, the peranakan elite controlled the island's Chinese

* The main points put forward in this article are more thoroughly developed and documented in my thesis, "Opium Farms in Nineteenth Century Java: Institutional Continuity and Change in a Colonial Society, 1860-1910" ( $\mathrm{Ph}$.D. dissertation, Yale University, 1977). References to documents from the Dutch colonial archives used in subsequent notes, are abbreviated as follows: V, Verbaal; VKG, Verbaal Kabinet Geheim; GG, Governor-General; MvK, Minister of Colonies; DBB, Director of the Colonial Service. Example: $\mathrm{V}$ 6/7/1882/5 means that the letter or document preceding it can be found in a Verbaal dated 6 July 1882 and numbered 5. 
population and wielded considerable influence in the furtherance of their own special interests. Central to their success in doing so were two institutions, both products of evolution within the colonial state: the Chinese Officer System and the Opium Farm System. The first was an institution of civil authority; the second was an economic institution, an institution which had become by the nineteenth century the fundamental source of peranakan wealth and power.

From the time of their first arrivals in the Indonesian islands the Dutch engaged in a prosperous partnership with the Chinese they met there. The intermediary commercial services of Chinese traders in Java, as well as the productiveness of Chinese laborers, craftsmen, and farmers--sugar growers and millers particularly-were crucial to the enterprises of the Dutch East India Company. In regional trade and in retail marketing the Company depended upon the Chinese. As the colony grew, so did a Chinese community, evolving slowly within the context of the conditions and opportunities of expanding European hegemony. In this way a small but stable Overseas Chinese community developed, formed by the dual process of intermarriage among the mixed-blood offspring of Chinese-Indonesian liaisons and the absorption of new immigrants from China. By the beginning of the nineteenth centory this society possessed a distinct culture, called peranakan, derivative of both Hokkien and Indonesian elements but unique to itself. In peranakan society a variety of Malay was the language of home and business, Dutch political authority was accepted and considered good, and status accrued most abundantly to the commercially successful. ${ }^{1}$

In the effort to exercise control over their Chinese population in Java, the Dutch chose the expedient local harbor town tradition of appointing headmen from each group, assigning them responsibility for tending to the affairs of and extracting fees and taxes from their communities. The first Chinese headman under Dutch aegis was So Beng Cong, appointed in Batavia in 1619. His appointment was the first in a sequence of hundreds during the following centuries, as the Dutch discovered the utility and convenience of governing the Chinese population in this manner. By the mid-nineteenth century nearly every city and town in Java had its own Chinese headmen, often a full hierarchy of them. Having begun by adapting Portuguese usage with the military title of Kapitan, the Dutch gradually added ranks above and below: Majoor, Kapitan, and Luitenant, and beneath them Wijkmeesters. These were Java's Chinese officers. Chinese officers performed many specific functions. They kept the Chinese census, collected the head tax, levied fines, and issued permits; they settled civil disputes and advised the colonial courts as to the character of Chinese witnesses and defendants. Generally, they were to maintain peace and order among their own and exercise surveillance over the community as a whole, reporting irregularities to the Dutch administration. They were a buffer between the Chinese population and Java's white rulers, and their power was considerable. ${ }^{2}$

1. See G. William Skinner, "The Chinese of Java," in Colloquium on the Overseas Chinese, ed. Morton H. Fried (New York: Institute of Pacific Relations, 1958), pp. 1 and 2, and "Java's Chinese Minority: Continuity and Change," Journal of A sian Studies, 20, no. 3 (May 1961), pp. 356-57.

2. B. Hoetink, "Chineesche Officieren te Batavia Onder de Compagnie," Bijdragen tot de Taal-, Land-en Volkenkunde [hereafter BTLV], 88, no. 78 (1922); C. R. Boxer, "Notes on Chinese Abroad in the Late Ming and Early Manchu Periods Compiled from Contemporary European Sources (1500-1750)," T'ien Hsia Monthly (December 1939), pp. 462-63; and J. E. Albrecht, Soerat Ketrangan dari pada hal kaadaan Bangsa Tiina di Negri Hindia Olanda (Batavia, 1890), pp. 12-29. 
In selecting Chinese officers, the Dutch sought to identify the recognized leaders in the Chinese community. These were almost always well-to-do merchants who were already affiliated with Dutch enterprises in some comprador function. Most of them held one or another of the government revenue farms or concessions--for running markets, collecting port fees, or selling salt or opium. From early Company days forward, entrepreneurial success, the acquisition of revenue farms and monopoly concessions, and appointment as Chinese officers went hand-in-hand. By the mid-nineteenth century, one government monopoly dominated all the others; this was the Opium Farm.

Early European traders in Java found a ready market for opium, and, as the Dutch East India Company gradually gained ascendancy over its rivals, it was quick to claim monopoly over the importation of opium. In the important treaty signed between the Company and the Sultan of Mataram in 1677, for example, opium is mentioned explicitly, along with cloth goods, as being subject to exclusive handling by the Dutch. In the years that followed, the Dutch made certain of their control over the opium trade, monopolizing its importation and controlling its internal distribution by selling retail franchises to wealthy local Chinese merchants. This was done on an ad hoc basis throughout the eighteenth century, until the demise of the Company. In 1809 Governor-General Herman Daendaels established an island-wide system for controlling the distribution and sale of opium products, which, with various adjustments, prevailed until the century's end. ${ }^{3}$

The Opium Farm System worked as follows. The Dutch continued to monopolize the importation of opium into Java. Once in Java the opium was sold by the colonial government at fixed rates to the wealthy merchants who had been awarded regional distribution franchises, usually by having offered the highest bid in public auction. These regional distributors, virtually always Chinese, were Java's opium farmers. Ordinarily, the size of their farms was coequal to that of one of Dutch Java's Residencies. It often happened, however, that one opium farmer--and the syndicate of financial backers he headed--controlled the opium farms in several Residencies; and occasionally during the nineteenth century one opium farmer monopolized the opium business of as much as one third of the entire island.

Opium farmers themselves seldom bothered with the day-to-day transactions of their franchises. They usually employed professional managers to conduct the business of the farm. This involved the manufacture of opium products, the distribution of these products to some fifty local stores, and the collecting and auditing of the opium receipts as they made their way from thousands of customers up through the organization to the top. Opium farms employed hundreds of people, from clerks and coolies in local stores, to technicians and chemists in the manufacturing facilities. The trade in opium hardly ended at the level of the official opium farm stores. These were in fact distribution centers from which local peddlers bought opium products to be resold in smaller shops and opium dens, and door-to-door in the villages. The opium farms' most important customers were Javanese farmers, laborers, and itinerant folk who spent only a few pennies a day to buy a small packet of tobacco or other leaves which had been soaked in opium. This petty trade was the heart of the opium business in Java, and it was always vulnerable to black-market competition. Because of this, opium farms always employed teams of informers, spies, and toughs to police their monopolies. These mata-mata were ordinarily the only members of the entire opium farm organization who were not Chinese. ${ }^{4}$

3. The history of the opium trade in Java during the Company period is discussed in J. C. Baud, "Proeve van eene geschiedenis van den handel en het opiumgebruik in den Archipel," BTLV, 1 (1853), pp. 79-220.

4. For a detailed description of opium farm organizations, see Rush, "Opium 
It was the practice of the Dutch to restrict the movement and residences of Java's Chinese population. For the most part they obliged the Chinese to live in special quarters in the major cities and towns, and subjected their travel and trade to strict surveillance. Passes were required to move from place to place, to be issued and checked by the Chinese officers. Holders of government revenue farms, however, had privileged access to the interior. An opium farmer of necessity had employees and agents throughout the countryside. So, too, on a much smaller scale, did the pig and buffalo farmers--who collected taxes on the slaughter of animals--and the contractors who distributed government salt. By virtue of their privileged access, these individuals and their employees were in a special position to engage in a full range of economic activities. Controlling the opium farm, which was the largest and most extensive revenue farm, therefore meant much more than reaping the profits of the opium business itself; it meant being in a position to dominate the commercial life of an entire region, all the more so when the opium farmer or his colleagues also controlled the smaller revenue farms as well. This was frequently the case. An opium farm represented, then, the broad commercial interests of one individual and his associates, employees, and clients. It was really a vast commercial organization, and, in terms of social and economic relations, a powerful patronage network.

It was into the outer reaches of these patronage networks that many of Java's new Hokkien immigrants were absorbed, initially perhaps in menial capacities by employers with the same surname. The most clever and energetic among them might attract the attention of a more influential patron, be placed with the opium farm organization, make a good marriage, and eventually advance to affluence and prominence. Absorption into an opium farm-dominated patronage network, and then assimilation to peranakan society and mobility within it, was the most desirable path for the newly arrived Chinese immigrant.

Prominent opium farmers were inevitably Chinese officers too; if they were not, then members of their extended families or business colleagues were. Dutch colonial laws giving wide civil authority to Chinese officers and monopoly privileges to opium farmers, therefore, permitted a small group of wealthy peranakan to embrace the entire local Chinese population. This is how the Dutch imposed authority, indirectly, upon the Chinese of Java.

However, among the peranakan elite themselves intense rivalries existed. The most public manifestation of these was competition for the opium farms, but for the reasons just mentioned, their real object was a near monopoly of trade in one or several Residencies. It was essentially a rivalry among opium farmers and potential opium farmers, in which the farmers had an extraordinary advantage. Many farmers retained positions of dominance continuously for years, and passed their positions on to sons, nephews, or protégés. But a variety of factors, including mismanagement, betrayal by a key partner, or economic depression, could weaken a farmer's position and make him vulnerable, creating a situation in which an opium farm might change hands--and with it the related commercial bounty. Farm competitors therefore did their best to undermine the opium farm, by selling black-market opium in their territories and by gaining access by whatever means to the rural markets. Sometimes, for example, the prices paid to the Dutch for control of minor revenue farms were ludicrously high because farm competitors found them so useful in penetrating these markets; farmers, of course, often found it worth their while to pay an even higher price to keep them out.

Farms," ch. 2. 
This competition was a basic theme of Chinese life on Java. Among themselves the Chinese called it "the battle of the kings." 5 In waging their internal battle opium farmers exercised considerable influence at all levels of society--from the village, to the Residency capital and in Batavia. To do so effectively meant accommodating to the powers and conventions of the village world, to the needs of priyayi officials who presided over it, and finally to the Dutch Colonial Service. Java's farm Chinese were experts at manipulating the system.

Successfully waging the war for markets in the village world meant coming to terms with its masters. Javanese regents, heirs of the ruling regional families of the preceding era and now Dutch clients, variously ruled and administered their districts at the head of an aristocratic administrative corps. In pyramid form the priyayi hierarchy of regent, wedana, and assistant wedana, fleshed out at each level by other functionaries, clerks, and apprentices, formed the link between the headmen of the villages and the overarching Dutch administration. Local affairs were entirely in their hands; and the farm Chinese needed their cooperation.

This was especially true because the struggle for the opium and other markets was intimately involved with the world of rural crime and crime detection. There was, first of all, the black market in opium. Controlling the black market was an essential task of the opium farm, but the farm could not do it alone. Second, almost any legitimate and officially sanctioned Chinese activity in the interior provided the opportunity, rarely lost, to engage in a related criminal activity. Opium smuggling was the most important of these, but there were others. Finally, the usual routines for investigating crimes in rural Java, whether employed by farm mata-mata or local priyayi police, lent themselves to a regimen of deliberate harassment of unwanted competitors. For these reasons farm concern for the detection and punishment of crime was an in terested one. Javanese conventions for dealing with crime in the countryside, and the way in which these conventions meshed with the institutions of Dutch colonial authority--the colonial courts in particular--created an environment in which Chinese influence could be brought to bear with great effect.

The commonest opium-related crime in Java was the illegal possession of a petty quantity of opium by a Javanese; the next commonest was the illegal possession of a similarly petty quantity by a Chinese. Violations were tried before the Police Roll, the lowest colonial court which handled criminal cases. The police roll was therefore an important element in the opium farm's effort to fight the black market in rural petty trade. It was also an effective coercive tool which helped the opium farmer make good his broader commercial claim to the whole Residency.

The Dutch Resident, or more commonly the Assistant Resident, held police roll twice weekly, often on the verandah of his own dwelling. Here gathered the local priyayi and their police subordinates, all the relevant complainants and witnesses, the Moslem and Chinese advisers, and other interested parties including, in opium cases, local representatives of the opium farm. The jaksa, an indigenous legal official, acted as clerk of the court and prepared a summary of the results of a priyayi investigation for the presiding official. Based on this report, the Assistant Resident interrogated the defendant and witnesses, heard the advice of the Moslem adviser or Chinese officer, consulted expert opinion (of the local opium chemists for instance), and finally reached a decision. He found the defendant guilty or not guilty, and imposed a sentence. Once imposed, the decision could not be appealed.

Prior to 1866, public whipping was among the commonest punishments meted out at the police roll. Lesser police roll sentences ranged from a few days in the local

5. Liem Thian Joe, Riwajat Semarang (Semarang: Ho Kim Yoe, 1933[?]), p. 141. 
jail to three months unpaid labor on public works. Offenders could also be fined up to f.25--after 1877, f.100--and jailed for failure to pay. Such sentences were formidable in terms of the local rural economy, and were made even more so by the fact that, even before their cases were heard, suspects frequently spent days or weeks detained by the wedana or police mantri pending completion of the investigation. Police roll justice was arbitrary and occasionally brutal. Based on the discretion of the presiding Dutch official, almost anything could be construed as an offense against public order. Thus, alongside theft, arson, and opium and gambling violations, punishable offenses included selling charms, "insanity," sleeping under the trees, seduction, overtaking the Resident's carriage, and wizardry. In addition, despite the 1866 ban, the physical abuse of suspects under police roll interrogation still occurred well into the $1880 \mathrm{~s} .{ }^{6}$

The sparseness of the Dutch administrative presence in Java and the legendary workload of its officials, not to mention the more difficult problem of penetrating the intricacies of petty crime and rivalries in the village world, meant that police roll judges were almost completely dependent upon the investigations carried out by their priyayi subordinates. In practice the police roll, though it may well have acted in Dutch interests in a general way, i.e., as a concrete, local manifestation of Dutch authority, could be used by others in a far more specific way. Persons in a position to influence the outcome of local criminal investigations could frequently manipulate the courts in their own interests, legitimate or otherwise. The farm Chinese were among those who most successfully adapted and exploited in this way the conventions for dealing with crime in the village world.

In colonial Java, solving crimes was largely a priyayi responsibility. The regents, wedana, and assistant wedana who formed the upper level of the priyayi administrative structure were charged by their Dutch patrons with producing clear unambiguous solutions, ketrangan, to crimes which disturbed the prized and reassuring rural calm or threatened colonial revenues. The assistant wedana was the priyayi official most immediately responsible for pursuing a criminal investigation in his subdistrict. When a village headman summoned him to the site of an offense, the assistant wedana officially took over the investigation. It was his job to notify his priyayi colleagues of the crime, to lead house-searching activities (in cases of theft or black-market opium for example), to confiscate evidence, to hold suspects, take eyewitness reports, and record accusations, in short, to conduct a complete legal investigation. His ketrangan, officially known as a provisional investigation, was used by the Assistant Resident to determine whether the case should be heard in court and at what level. At a later stage, the jaksa would use it as a basis for prosecuting the case before either the police roll or a higher court. Such ketrangan were therefore central to the efficient resolution of local disturbances and prosecution of crime. For this reason, priyayi careers could depend upon the success with which the investigation was prepared. ${ }^{7}$

6. See the list of 104 miscellaneous offenses which had been punished by police roll judges in "Versameling qualificatien van vergrijpen ter policierol gestraft," Indisch Weekblad van het Recht (1866), no. 176.

7. On ketrangan and their importance, see: Onderzoek naar de mindere welvaart der inlandsche bevolking op Java en Madoera, 12 vols. (Batavia: Landsdrukkerij, 1905-14), vol. 8B : Overzicht van de Uitkomsten der Gewestelijke Onderzoeking naar 't Recht en de Politie, pt. 2: Slotsbeschouwingen (Batavia: Roygrok, 1912), pp. 120, 122, 123 [hereafter Mindere Welvaart Onderzoek]; Memorie van Overgave, L. Ch. H. Fraenkel, Resident of Rembang (October 1901-July 1907) in V 5/3/1908/ 36; and Heather Sutherland, "Pangreh Pradja: Java's Indigenous Administrative 
Success in producing ketrangan depended ultimately upon a priyayi's links with the village world beneath him. These he maintained through his subordinate clerks and police mantri, who in fact performed much of the work that went into conducting a preliminary investigation. In turn, their success depended upon the cooperation of local village headmen and of a distinct class of village figures who specialized in criminal affairs--the jagabaya.

Jagabaya distinguished themselves from ordinary villagers by their supravillage experience and an aptitude for intrigue. As practitioners of the magical and martial arts, and adepts of the science of invulnerability, they might attract young disciples in the same way as the more orthodox Islamic teachers. Their métier was crime, its perpetration and detection, and their services were for hire. Thus they frequently appear alongside other local functionaries as village police (kapetengan) appointed by headmen to protect villages from banditry and arson, and as detectives and "secret police" in the service of headmen, priyayi officials, and Dutch administrators. As such they often acted as ketrangan-makers, specialists in producing airtight (and often false, evidently) solutions to criminal investigations which the Dutch required of their native subordinates. The social environment of the jagabaya was much broader than that of the ordinary villager. Jagabaya gathered in opium and gambling dens and consorted among the fringe elements of Javanese society: dancing girls, prostitutes and pimps, traveling show folk, magicians and con-men, brigands, fences, and thieves. It was their familiarity with these elements and their equal familiarity with the village world that made them such valuable resources. Jagabaya were, therefore, enlisted in the service of not only the native and Dutch authorities, but also a variety of other individuals and groups whose interests penetrated the village world. Chief among these were the Chinese. Agents recruited from among the jagabaya class were key participants in the struggle between competing Chinese interests for control of Java's rural markets. ${ }^{8}$

As opium farm mata-mata, jagabaya worked alongside Chinese mata-mata to play an aggressive role in finding black marketeers in the farm territory and bringing them to court. Tacitly condoned investigative excesses by mata-mata--including coercion, brutality, and invasion of privacy--and the colonial laws which punished possession of nonfarm opium by fines and hard labor, gave Chinese opium interests a great deal of leverage in the village world. Farm-initiated court proceedings could be used to punish not only legitimate black-market violators, but to harass competitors of all sorts. The clandestine opium frame-up in which farm mata-mata or local police feigned to discover a small cache of planted illegal opium in someone's house was the commonest form of such harassment. Victims of such ploys could easily find themselves placed on a labor gang for from three months to over a year.

Corps and its Role in the Last Decades of Dutch Colonial Rule" (Ph.D. dissertation, Yale University, 1973), p. 112.

8. The terms kapetengan, jagabaya, and jagadesa were all used to describe those who held official or semiofficial positions as police within the village structure. Other terms associated with such figures in a less specific way were bramacorah, blateran, and weri. See Onghokham's discussion of the role of weri--which he translates as spies--in nineteenth-century Madiun. Onghokham, "The Residency of Madiun: Priyayi and Peasant in the Nineteenth Century" (Ph.D. dissertation, Yale University, 1975), pp. 294-95. On jagabaya, see: "Historische Nota over de dessabesturen op Java," Koloniaal Verslag van Nederlandsch Indië (1877), Appendix N, p. 5; and Mindere Welvaart Onderzoek, vol. 8b, pt. 2, pp. 116-17. 
The actions of the farm and its personnel in these efforts deviated little from the prevailing conventions for solving crimes in the village world. Frisking, house searching, and the preventive detention of suspects were the stock in trade of all Java's rural detectives, from regents to the local kapetengan. Farm personnel made routine use of all these techniques; in fact, the Chinese considered the authority to do so to be a firm, though unwritten, part of the farm contract. ${ }^{9}$ The "set-up," in which an individual was framed to appear guilty for a crime he did not commit, and frequently convicted on the basis of craftily contrived evidence and false testimony--the work of jagabaya and village-wise Chinese mata-mata--was a classical device of harassed headmen and priyayi under pressure to present their superiors with ketrangan. Likewise, the fabrication of cases for purposes of revenge, and covering up one's own complicity in criminal affairs by foisting the blame on another, were hardly confined to the Chinese; complaints about these activities were general to the administration of justice at the village level throughout central and east Java. ${ }^{10}$ Farm activities in the field of crime and crime detection differed markedly from the norm, however, in one important respect. In concert they were directed toward the attainment of a specific Residency-wide goal: furthering the commercial interests of the opium farmer and his associates and clients.

To bring cases into the colonial courts, farm interests could not rely solely upon their own agents. Farm mata-mata had to maintain a close working relationship with local kapetengan and the police mantri who served directly under priyayi officials. The fact that Javanese mata-mata, kapetengan, and police mantri were frequently recruited from the same jagabaya group--that is, were most likely acquaintances, if not comrades--generally facilitated such cooperation. In addition, the farm routinely subsidized these elements and their priyayi superiors by providing salaries, bonuses, and bounties in return for their efforts on behalf of the farm. ${ }^{11}$ As a result, almost all farm-related cases which were prosecuted in the police roll and higher courts, though initiated by farm personnel, involved the active participation of local kapetengan, police mantri, and priyayi.

For opium farm interests, then, Javanese collaboration was essential to the investigation and prosecution of farm-related crime. Such collaboration was selfinterested on both sides, for the priyayi too had something concrete to gain by protecting the local farm. Specifically, by means of gifts, bounties, loans, and salaries, the opium farm Chinese helped subsidize the regal manners and customs expected of priyayi by tradition--manners and customs which their own resources, dwindling markedly during the nineteenth century as a consequence of Dutch re-

9. In 1876, when Batavia forbade farm employees both frisking and house searching (a ban which was without effect), Solo farmer Tio Siong Mo wrote: "The authority to inspect the bodies of natives and Chinese, and to search their houses, is so old, and flows so naturally from the native's conception of the mutual interests of Farmer and Government, that they are indeed considered an ongoing proviso of each Farm contract." Tio Siong Mo, "Aan de Tweede Kamer der Staten-Generaal," February 1, 1876 in $\mathrm{V} 17 / 8 / 1876 / 74$.

10. See, for example, Mindere Welvaart Onderzoek, vol. 8b, pt. 2, pp. 122-23.

11. An interesting case arose in Bagelen in 1871 when Chief Jaksa mas ngabehi Atmodirono made excessive demands of the opium farmer in return for his cooperation, insisting on money and control of the buffalo farm. GG to MvK, March 11, 1872 in VKG $30 / 5 / 1 / 1872 / W 8$. 
forms, failed to support. ${ }^{12}$ In doing so, especially by providing a source of patronage, the Chinese helped to shore up the strained priyayi social structure.

As a result, higher native officials were frequently deeply in debt to farm Chinese. These loans were often more in the nature of considerations than business transactions, and were not customarily recorded in notarial acts or promissory notes; they also were commonly disguised as another sort of transaction--a particularly popular method being the "purchase" by a Chinese of a gamelan or other property, for the continued use of which the priyayi seller paid a monthly "rent." Precise figures about such indebtedness are therefore almost uniformly lacking. However, investigations into the private affairs of regents, which occurred occasionally when their official performance diverged from Dutch expectations, revealed that they were nearly always substantially in debt to Chinese. ${ }^{13}$

Alongside loans, priyayi received gifts from the farm Chinese. Like their Dutch counterparts, priyayi officials were the recipients of tanda hormat (tokens of respect) and sumbangan (contributions)--in some cases including their personal opium supplies. These loans and gifts played an important part in helping them keep up the appearance of regality and meet social expectations. More important to reinforcing the priyayi structure, however, were the various ways the farm acted to subsidize the priyayi corps. These, as we have noted, included regular payments, frequently at the district level and below, to encourage police work on behalf of farm interests. Large confiscations of nonfarm opium, for instance, brought sizeable bonuses for the participants; and local farm managers were known to express their gratitude tangibly for even the smallest effort.

The payment of such bounties and subsidies reinforced the priyayi structure by providing a source of patronage. Priyayi officials could disperse bounty and subsidy money downward among their subordinates (most of whom received regular salaries from the government), and in doing so strengthen traditional ties of personal loyalty.

The harmonization of interests which characterized opium farm Chinese and priyayi relations found a parallel in those between the Chinese and the Dutch. At this level, too, the farm Chinese succeeded in taking advantage of certain distinct features of Java's colonial society to protect and further their interests.

The first and greatest strength of an opium farmer was the revenue he provided the colonial treasury. This was considered so crucial to generation after generation of officialdom that it effectively undermined any sincere effort to deal with what were thought by some to be the negative social and physical consequences of opium smoking. Opium underwrote a significant portion of Holland's colonial enterprise (from 15 to 20 percent annually) and it was the farmer who effectively, and at no cost to the Dutch, transformed raw opium into a fund of millions. Over the years, therefore, a tacit assumption prevailed: how opium revenues were made was less important than how much of them reached the colonial coffers. This assumption, of which both opium farmers and local Dutch officials were well aware, related closely to two others, highly important to individual careers in the Colonial Service: that opium revenues reflected general prosperity, and that general prosperity was

12. Among the many evidences of the growing financial plight of the priyayi are advertisements, like the one in de Locomotief, October 17, 1867, no. 83, announcing the sale of Javanese treasures, in this case a gamelan.

13. The case of $R$. M. Tirto Noto is discussed in DBB to GG, May 5, 1888, no. 2601 (Geheim) in V 16/7/1888/6. 
a reflection of prudent and wise administration. It therefore profited a man's career, so it was felt, if his Residency or district provided abundant farm revenue. This is one reason why Residency-level officials were often satisfied to give free rein to the farmer and his organization.

Another reason that Dutch Residents and their subordinates in the Colonial Service did so was that farm activities, no matter how flagrantly in violation of the statutes, rarely constituted a major danger to public calm or safety. The excessive workload facing members of the Colonial Service--"living, eating, and sleeping with pen in hand," as Louis Couperus put it--also mitigated against vigorous attention to the affairs of opium farmers and their competitors, as did the frequent transfer of Residents and Assistant Residents. ${ }^{14}$ Generally speaking, the local Dutch administration was predisposed to let the Chinese have their own way.

But opium farmers could not rely totally on this acquiescent environment. Zealous officials were not unknown, and negotiations with the government on matters crucial to the farm occurred on a regular basis. Beyond that, farmers had occasionally to seek both compensation and redress from the authorities, and they sometimes faced the threat of legal prosecution. In such instances, farmers moved actively, lobbying with the administration and defending their interests in court. Fully understanding the implications of Java's racial caste system, farmers made shrewd use of European intermediaries, and Java's best Dutch lawyers counted opium farmers among their clients.

Perhaps the most prominent Indies lawyer involved in farm and opium affairs was C. Th. van Deventer. During his Semarang legal career he represented several farm clients. In 1890 , when the major kongsis faced bankruptcy and loss of their farm leases, he advised and appeared on behalf of the two strongest opium consortiums in central Java, the Ho group of Semarang, headed by Farmer Ho Tjiauw Ing, and Han Liong Ing's "Kediri kongsi." Van Deventer's services included personal influence as well as legal appearances; in late 1889 he wrote personally to the Governor-General on behalf of Ho Tjiauw Ing and his associates, calling them upstanding citizens of official importance. ${ }^{15}$

Europeans also served Chinese opium farm interests in other intermediary roles, as lobbyists, and, on rare occasions, as members of an opium farm consortium. Chinese and Europeans were business partners in other endeavors as well; several such partnerships emerged after 1870 in the exploitation of long-term leases of Javanese land for commercial agriculture. In addition, European professionals sometimes worked for Chinese owners of plantations and processing plants. All of these affiliations strengthened the hands of farm Chinese in their relations with the authorities.

The common nonchalance of Dutch administrators about the activities of opium farmers was further encouraged by an environment among the Residency elite in which the exchange of favors was raised to the level of adat (accepted and honored custom). Both Dutch colonial administrators and their Javanese counterparts lived in a social atmosphere in which their respective positions encouraged them, if it did not require them, to live beyond their means. The colonial good life in Java--

14. Louis Couperus, De Stille Kracht (1900; Amsterdam: Veen, 1951), pp. 36-37.

15. C. Th. van Deventer to GG, October 14, 1889 in V 22/2/1890/63. Van Deventer said that his Chinese clients were his most congenial. Dr. H. T. Colenbrander and J. E. Stokvis, eds., Leven en Arbeid van Mr. C. Th. van Deventer (Amsterdam, 1916), 1, p. 167 . 
including the maintenance of large households, lavish entertaining, and Java's renowned hospitality--was in part subsidized by means of a cluster of social customs which permitted well-heeled Chinese supplicants to curry favor with the Colonial Service. Many of these activities can be grouped under the general name of sumbangan. Javanese tradition sanctioned the receipt of sumbangan by priyayi officials. Regents, for instance, were entitled to sumbangan on special occasions and routinely received unsolicited gifts from people with specific requests to be granted or general interests to further. ${ }^{16}$ By the nineteenth century the sumbangan custom had long since permeated the European official class and was particularly characteristic of interelite relationships. Opium farmers were among those who made masterful use of its possibilities.

One of the commonest forms of sumbangan was the offering of gifts to Dutch officials on festive occasions, for which the multicultural calendar of the Indies offered innumerable opportunities. Each Chinese New Year, for example, officials received tanda hormat from supplicant Chinese, gifts which might range in extravagance from Manila cigars and European liquors, to expensive silks, gems, and jewelry "for the Mevrouw." Birthdays of administrators and members of their families, as well as Christian holidays, offered similar opportunities to please the administration. Another form of sumbangan was the long-term loan to newly appointed officials of items such as furniture, carriages, horses and the like. In some Residencies wealthy farm Chinese owned the permanent furnishings of the Resident's official dwelling, like gilded mirrors, chandeliers, and draperies, and "loaned" them to each successive occupant. ${ }^{17}$

Another related form of sumbangan was the routine provision of food and supplies, either free or at discount, to the Resident's and other official households. Liem Thian Joe, for instance, writes of nineteenth-century Semarang Residents receiving daily provisions of eggs, chickens, beef, pork, vegetables, rice, and fish-all fancy grade--on the opium farmer's account. ${ }^{18}$ Unsecured low-interest loans to friends and relations of officials (prodigal sons, newly arrived nephews, and so forth) were yet another form of sumbangan. Finally, the habit of Indies Europeans of purchasing heavily on credit from Chinese shops, a habit which Chinese did little to discourage, also helped to subsidize the petty opulence of the life of the ruling elite.

The archtypical sumbangan institution in colonial Java was the auction. It was customary for officials to auction off their private possessions and household furnishings--from flower pots and tea spoons to carriages and cattle--at the end of each posting. Such auctions offered a final opportunity for an official's subordinates, associates, and other well-wishers to demonstrate their respect by purchasing items at outrageously exaggerated prices. On such occasions common tea cups reportedly brought as much as f.500, and native officials from regents to lowly mantri pledged a month's salary to buy the discarded riff-raff of the Residency house. ${ }^{19}$ For opium farmers, ostentatious bidding at these auctions served two related purposes: it was a public demonstration of their good character and generosity; and at the same time it served as a hint to the incoming official (who would be

16. Sutherland, "Pangreh Pradja," p. 105.

17. Among the many descriptions of these activities in contemporary sources is M. C. Piepers, Macht tegen Recht (Batavia: van Dorp, 1884), pp. 161-62.

18. Liem, Riwajat Semarang, pp. 148-50.

19. See H. E. Steinmetz, Indische brieven aan een Staatsraad (Haarlem: Bohn, 1888), pp. 51-52. 
roundly informed about such matters) of what he might expect should his relations with the farm be as felicitous.

If highly placed officials were susceptible to the blandishments of farmers, lowranking police and customs functionaries, who by caste belonged to the ruling class but whose incomes made a comparable material life a vain hope, were all the more so. Such subordinates, recruited from among the poorer Europeans and the Eurasian population--the loose ends of colonial Java's racial elite--were nearly universally considered untrustworthy by their superiors. It was widely known that low-ranking police and customs personnel supplemented their incomes by accepting additional stipends from farmers in return for vigor in protecting their interests.

At every level the farm Chinese found ready accomplices. The success with which they exploited the formal machinery of the Dutch establishment and other less formal aspects of the colonial administration and status system, as well as the realities of the village world, illustrates the flexibility of Java's colonial institutions, and the interdependence of the elites who presided over them.

These patterns of collaboration continued until the last decade of the nineteenth century, when a variety of powerful economic, social, and political forces in Java and Holland coalesced to bring about significant change. Opium farms were abolished, the Chinese were removed from the opium business, and, slowly, the Chinese officers died off and were not replaced. Java's Chinese were now more directly subordinated to the formal administrative apparatus of Netherlands India, which the Dutch had been systematizing over several decades, and in which, with each generation, priyayi officials became more and more like bureaucrats in the Western mold. This new context brought forth new institutions for maintaining social control and for wielding influence. For the Chinese, these new institutions were less cohesive socially and economically--Java's China population had become larger and more diverse--and with respect to protecting important interests, more oppositional than collaborative. 